J. Med. Microbiol. - Vol. 39 (1993), 159

(C) 1993 The Pathological Society of Great Britain and Ireland

\title{
ANNOUNCEMENTS
}

The Royal College of Pathologists. One-day Symposium

\section{Current Topics in Veterinary Pathology}

Wednesday 20th October 1993

to be held at the Royal College of Pathologists, 2 Carlton House Terrace, London, SW1

Provisional programme

Chairman: Professor H. M. Pirie (University of Glasgow)

Feline Immunodeficiency Virus Infection, Professor O. Jarrett (University of Glasgow);

Pathogenesis and Control of Rabies, Professor P. Pastoret (University of Liege); Bovine Spongiform Encephalopathy, Pathogenesis and Diagnosis, Mr R. Bradley (Ministry of Agriculture, Central Veterinary Laboratory, Weybridge); The Pathogenesis of Pestivirus Infections, Dr J. Brownlie (AFRC Institute for Animal Health, Compton, Berks).

Chairman: Professor D. F. Kelly (University of Liverpool)

Rodent Liver Carcinogenesis, Dr J. G. Evans (Fisons Pharmaceuticals, Leicestershire); Zoonotic Diseases of Non-Human Primates and other Laboratory Animals, Dr A. Baskerville (PHLS);

Platelet Function, Dr R. J. Evans (University of Liverpool); Toxicopathology of Biotechnology

Products, Dr T. Anderson (Roche, USA).

Further information from: Scientific Meetings Officer, The Royal College of Pathologists, 2 Carlton House Terrace, London SW1Y 5AF (Tel: 071930 5862; Fax: 071321 0523).

\section{3rd International Congress}

\section{The Immune Consequences of Trauma, Shock and Sepsis - Mechanisms and Therapeutic Approaches}

Munich, Germany 2-5 March 1994

The deadline for abstracts is October 30, 1993

Further information from:

Dr Eugen Faist,

Ludwig-Maximilians-Universität Munich,

Klinikum Grosshadern,

Dept. of Surgery,

Marchioninistrasse 15

8000 Munich 70 , Germany

Tel: 49-89-7095-3441

49-89-7095-3436

Fax : 49-89-7095-2460 